\title{
Tertiary Education Trust Fund Policy on Essential Physical Infrastructure and Instructional Materials and Equipment in South East, Nigeria: Assessment
}

\author{
Anorue, Chuks E. ${ }^{1}$, Ikediugwu, N. (Prof.) ${ }^{2}$ \\ ${ }^{I}$ Department of Educational foundations and Administration, Alvan Ikoku Federal College of Education, Owerri (affiliate of \\ University of Nigeria Nsukka) \\ ${ }^{2}$ Department of Educational Management and Policy, faculty of Education, Nnamdi Azikiwe University, Awka
}

\begin{abstract}
The purpose of this study was to assess the Tertiary Education Trust Fund policy implementation for universities improvement in the South - East of Nigeria. The study was guided by four research questions and four hypotheses. The researcher adopted descriptive survey design for the study. The population of the study is $\mathbf{7 6 5}$ staff of the federal and state public universities in South- East, Nigeria. There was no sampling since the number of Heads of Departments, Deans of Faculties, and TET Fund Committees of the Universities was manageable, the entire population was studied. Assessment of TET Fund Policy Implementations for Universities improvement questionnaire was used as instrument for data collection. The researcher also used a checklist to really ascertain the authenticity of the data provided by the respondents. Data were analyzed using Mean and Standard Deviation to answer the research questions and ANOVA was used to test the hypotheses at 0.05 level of significance. The findings from the results revealed that the extent to which Tertiary Education Trust Fund has implemented policy on provisions of essential physical infrastructure for teaching and learning for the universities improvement in SouthEast, Nigeria is low and there is significant difference in the mean ratings of the opinion of the respondents. The findings also revealed that the extent to which TET Fund has implemented policy on the provisions of instructional materials and equipments for teaching and learning and is low, and there is no significant differences in the mean ratings of the respondents opinion on the result. The researcher made some recommendations which includes: that TET Fund should diversify its provisions of essential physical infrastructure to cover other areas like provision of administrative blocks, water resource, hostel accommodation, staff quarters and others. TET Fund board of directors should improve to a large extent its policy on the provision of instructional materials and equipment especially in providing items like laboratory apparatuses, personal computers, lap top computers to staff, document cameras, among others.
\end{abstract}

Key words: Policy, implementation, universities improvement, teaching, learning

\section{INTRODUCTION}

$\mathrm{E}$ ducation in Nigeria and in Diaspora is a veritable instrument for national development and social change. This statement indicates the value of education. However, the value of education to any society is dependent on the amount of revenue pumped into it by the government of that nation.
Education to Assman (2002) is any act of experience that has a formative effect on the mind, character or physical ability of an individual. FRN (2013) defines tertiary education as the education given after past Basic Education institutions such as universities and other inter university centers. However, the National Policy on Education outlined the goals of tertiary education as.

\section{Contributing to national development through high level relevant manpower training; learning accessible and affordable quality learning opportunities in formal and informal education in response to the needs and interest of all Nigerians....p.39}

In supporting this view, Idogho (2011) points out that in Nigeria today and several other African countries, the problem which higher education must seek to address should include combating higher level poverty, hunger and famine, combating drought and dessert encroachment, address the increasing rate of HIV/AIDS pandemic and other sexually transmitted diseases, economic meltdown, pronounced fraud in every sphere of the society, eradicating high level corrupt practices among the leaders, among others.

It could be said that from Nigeria independence till 1980's, higher institutions in the country seemed to have pursued to tackle these challenges with vigour. The pursuit seemed successful, and the objectives and goals seemed maintained until 1980's and beyond when the decay of all tiers of education system become evidently clear, infrastructural facilities had almost collapsed, dilapidated or almost absent. Teachers and lecturers' moral was at its lowest. Enabling environment for conducive teaching and learning was absent (Nwakaudu, 2013).

Commenting on infrastructural decay, Idogo (2011) posits that the infrastructural inadequacies in the Nigerian Universities are other areas which pose hindrances to learning and research work. Odetunde in Idogho (2011, p.15) asserts: 'unfortunately, today students are learning in dilapidated buildings, environmentally depressing and learning disability situations, yet some of these students are still excelling', for the students, Idogho added, "it is simply a means to acquire 
certificates and not the development of their cognitive and social powers". It is of note that infrastructural decay in Nigerian Universities ranges from lack of provision and maintenance of classroom blocks, administrative blocks, conducive hostel accommodations, to befitting library and laboratory buildings. Insufficient office spaces for staff and poor or lack of staff quarters may have been counter productive in teaching and learning in these universities. The term "Infrastructure" refers to the basic systems and services that are necessary for a country or an organization such as buildings, transport, water, power supplies and administrative system (Hornby, 2000). Commenting on essential physical infrastructure development in Nigeria Universities for teaching and learning, Nwakaudu (2013) asserts that the key areas that have benefited from an action plan clearly spelt out in the Federal Ministry of Education Action plan, tagged "four year strategic plan, 2011-2015", include the construction and improvement of classroom/lecture theatres, the construction of new and improvement of existing laboratories, the construction and improvement of libraries and construction and improvement of administrative blocks. To Fulmer (2009), infrastructure refers to the fundamental facilities and systems serving a country, city, or area including the services and facilities necessary for its economy to function. It include technical structure like roads, bridges, tunnels, water supply, sewers, electrical grids, telecommunications and so forth, and can be defined as the physical components of interrelated systems, commodities, and services essential to enable, sustain or enhance societal living conditions.

In terms of instructional materials and equipment, Nigerian Universities seem to have been ill-equipped as teaching and learning in most areas seems to perhaps hinge only on postulations of theories and consolidation of old ones with less emphasis in pragmatic learning. Laboratory apparatuses for serious experimentations seem not to have been within reach to the students. Hence, Nigerian University students and professionals' inability to compete favourably with their international counterparts remains quite worrisome. This situation seems to be worst and more worrisome in the South East Nigeria with annual highest intake of students into the universities compared with other Zones of the country (ASCC, 2014). Minor and Trye in Ike, Chimezie, and Iwu (2002) describes instructional materials covering a wide range of visual and audio media from simple chalk board, complex overhead transparencies and computer. Ike, et al (2002) said that this means that teaching aids are tools for the teacher to use in his efforts to communicate with the learners and they are largely not self-supporting. Australian National University (2014) listed some teaching room support and equipment as follows: Information common computers, data projector, $35 \mathrm{~mm}$ slide projector, overhead projector, document camera, voice reinforcement system, push button control panel, touchscreen control, Aux input panel, remote management.

In order to correct the delay, the Federal Government of Nigeria in 2011, promulgated Act called Tertiary Education Trust Fund Act 2011 which repealed Education Tax Act Cap
E4 laws of the Federation of Nigeria 2004 and Education Tax Fund Act No. 17 of 2003. This Act came into effect in June 2011. It is an intervention agency set up to provide supplementary support to all levels of public tertiary institutions, with the main objective of using funding alongside project management for the rehabilitation, restoration and consolidation of tertiary education in Nigeria. Section 7 sub section 1(a-e) provides for the TET Fund specific objectives as the provisions and maintenance of:

Essential physical infrastructure for
teaching and learning; instructional
materials and equipment; research and
publications; academic staff training and
development, and any other need...(TET
Fund 2014, p. 4).

Provision and maintenance of essential physical infrastructure entails providing and maintaining facilities like: Laboratory buildings, classrooms and halls, administrative buildings and staff offices, power and water among others. On the other hand, instructional materials and equipment are all about providing and maintaining materials like library books, electronic media, consumables, laboratory apparatuses for teaching and learning in the universities.

\section{Statement of Problem}

The problem of this study is that despite all the loafty objectives of TET Fund and huge amount of hand which is $2 \%$ annual tax of all the taxable companies in the country which Federal Inland Revenue Services (FIRS) collects and reimburses to TET Fund who then distributed to the tertiary institutions with universities taking lion share according to the policy on sharing ratio, most lectures in the South East Universities in Nigeria still hold in overcrowded halls, dilapidated buildings, ill-equipped or not even equipped halls, lack of modern study equipments. Most lecturers still wonder without offices or ill-equipped offices for proper academic works. Worst still, what Idogho (2011) opines that tertiary institutions should endeavour to combat are still ravaging the nation-such as poverty, fraud, insecurity, outbreak of diverse diseases, corruption, brain drain, as well as poor medical equipment as most leaders still travel abroad at the slightest health challenge. In view of the mandate of TET Fund to reconstruct, rehabilitate and restore, yet South East Nigeria which produces the highest entrants into the universities every year is still lagging behind. It is against this background that the researchers decided to embark upon the study on assessment of TET Fund policy on Essential Physical Infrastructure and instructional materials and equipment for Universities improvement in the South-East Nigeria.

\section{Research Questions}

The following research questions were formulated to guide the study:

1. To what extent has TET Fund policy on the provision of essential physical infrastructure for effective 
teaching and learning been implemented for Universities improvement in the South-East Nigeria?

2. To what extent has TET Fund policy on the provision of instructional materials and equipment for teaching and learning been implemented for Universities improvement in the South-East, Nigeria?

\section{Hypotheses}

Two hypotheses were also generated to further guide the study:

1. There is no significant difference between the mean ratings of the Heads of Departments, Dean of Faculties and TET Fund Committee members on the extent TET Fund policy on the provision of essential physical infrastructure for teaching and learning has been implemented for universities improvement in the South-East, Nigeria.

2. There is no significant difference between the mean ratings of the Heads of Department, Deans of Faculties, and TET Fund Committee members on the extent TET Fund has implemented policy on the provision of instructional materials and equipment for teaching and learning for universities improvement in the South-East, Nigeria.

\section{METHOD}

The study adopted descriptive survey design and focused on the South-East region of Nigeria due to the zones excessive love for education and constant claim by the people for government marginalization in terms of distribution of essential amenities. 765 HODs, Deans of faculties, and TET Fund committee members of the ten public universities in the area were used for the study and as such there was no sampling. Researcher developed validated instrument called: assessment of TET Fund policy implementation for universities improvement (ATPIU) with three sections was used to collect data. The reliability of the instrument was carried out using crombach's alpha which yielded a reliability coefficient of 0.93 . A checklist was also developed to cross check the authenticity of the data collected by the questionnaire which also yielded a reliability coefficient of 0.81 using inter-rater and kappa coefficient. Data was analysed using analysis of variance (ANOVA) Statistics.

\section{RESULT}

Table 1: Mean rating on the extent to which TET Fund policy on provisions of essential physical infrastructure for teaching and learning has been implemented for the universities improvement.

\begin{tabular}{|c|l|l|l|l|l|}
\hline $\mathrm{S} / \mathrm{N}$ & $\begin{array}{l}\text { ITEMS: to what extent has } \\
\text { TET Fund implemented its } \\
\text { policy on the provision of } \\
\text { the following for } \\
\text { universities improvement in } \\
\text { the S/E Nigeria? }\end{array}$ & $\mathrm{N}$ & $\sum \mathrm{X}$ & $\overline{\mathrm{X}}$ & $\begin{array}{c}\text { Decisio } \\
\mathrm{n}\end{array}$ \\
\hline 1 & $\begin{array}{l}\text { Laboratory buildings for } \\
\text { teaching and learning. }\end{array}$ & 750 & 1875 & 2.50 & High \\
\hline 2 & $\begin{array}{l}\text { Lecture halls for quality } \\
\text { teaching and learning. }\end{array}$ & 750 & 2025 & 2.70 & High \\
\hline
\end{tabular}

\begin{tabular}{|c|c|c|c|c|c|}
\hline 3 & $\begin{array}{l}\text { Administrative blocks and } \\
\text { offices for effective } \\
\text { management of teaching } \\
\text { and learning. }\end{array}$ & 750 & 1200 & 1.60 & Low \\
\hline 4 & $\begin{array}{l}\text { Power (electricity) for } \\
\text { constant academic activities } \\
\text { for staff and students. }\end{array}$ & 750 & 1875 & 2.50 & High \\
\hline 5 & $\begin{array}{l}\text { Water resource for an } \\
\text { enabling academic life } \\
\text { especially for students. }\end{array}$ & 750 & 1200 & 1.60 & Low \\
\hline 6 & $\begin{array}{l}\text { Library buildings to } \\
\text { enhance proper research } \\
\text { works. }\end{array}$ & 750 & 1800 & 2.40 & Low \\
\hline 7 & $\begin{array}{l}\text { Hostel accommodations for } \\
\text { students to help cushion } \\
\text { transport }\end{array}$ & 750 & 1200 & 1.60 & Low \\
\hline 8 & $\begin{array}{l}\text { Information and } \\
\text { communications technology } \\
\text { (ICT) blocks to enhance } \\
\text { proper teaching, learning, } \\
\text { communications } \\
\text { research. }\end{array}$ & 750 & 1950 & 2.60 & High \\
\hline 9 & $\begin{array}{l}\begin{array}{l}\text { Auditoria for staff and } \\
\text { students }\end{array} \\
\text { functions, } \\
\text { workshops, seminars etc. }\end{array}$ & 750 & 1200 & 1.60 & Low \\
\hline 10 & $\begin{array}{l}\text { Staff quarters to ease staff } \\
\text { problems and to enable real } \\
\text { contacts with students. }\end{array}$ & 750 & 1200 & 1.60 & Low \\
\hline 11 & $\begin{array}{l}\text { Staff offices for serenity of } \\
\text { academic environment and } \\
\text { office works. }\end{array}$ & 750 & 1650 & 2.20 & Low \\
\hline
\end{tabular}

Findings made from the analysis of data presented on table one shows that the TET Fund's policy on the provision of some essential physical infrastructure like laboratory buildings, lecture halls, power and ICT units were rated high. On the other hand, some other essential physical infrastructure like Administrative blocks, staff offices water resource, library building, hostel accommodations and staff quarters were rated very low. On the whole, the obtained grand mean of 22.90 is lower than the expected grand mean of 27.50 which is an indication that the overall extent to which TET Fund's provisions of essential physical infrastructure for teaching and learning has been implemented for the universities improvement in the South-East, Nigeria is low.

Table 2: Mean rating on the extent to which TET Fund policy on the provision of instructional materials and equipments has been implemented for the universities improvement

\begin{tabular}{|c|l|l|l|l|l|}
\hline $\mathrm{S} / \mathrm{N}$ & $\begin{array}{l}\text { ITEMS } \\
\text { To what extent has TET Fund } \\
\text { implemented policy on the } \\
\text { provision of the following for } \\
\text { universities improvement in } \\
\text { the South- East, Nigeria? }\end{array}$ & $\mathrm{N}$ & $\sum \mathrm{X}$ & $\overline{\mathrm{X}}$ & $\begin{array}{l}\text { Deci } \\
\text { sion }\end{array}$ \\
\hline 12 & $\begin{array}{l}\text { Library books for proper } \\
\text { reading and referencing } \\
\text { culture. }\end{array}$ & 750 & 1875 & 2.50 & High \\
\hline 13 & $\begin{array}{l}\text { Electronic media for teaching } \\
\text { and learning. }\end{array}$ & 750 & 2025 & 2.70 & High \\
\hline 14 & Laboratory apparatuses. & 750 & 1200 & 1.60 & Low \\
\hline
\end{tabular}




\begin{tabular}{|l|l|l|l|l|l|}
\hline 15 & $\begin{array}{l}\text { Personal computers (PCs) for } \\
\text { teaching and learning. }\end{array}$ & 750 & 750 & 1.00 & Low \\
\hline 16 & $\begin{array}{l}\text { Data projectors for teaching } \\
\text { and learning. }\end{array}$ & 750 & 2025 & 2.70 & High \\
\hline 17 & $\begin{array}{l}\text { Magnetic Boards for lecture } \\
\text { halls. }\end{array}$ & 750 & 2025 & 2.70 & High \\
\hline 18 & $\begin{array}{l}\text { Necessary engineering } \\
\text { machines for the faculties. }\end{array}$ & 750 & 1800 & 2.40 & Low \\
\hline 19 & $\begin{array}{l}\text { Document cameras in the } \\
\text { lecture halls. }\end{array}$ & 750 & 1650 & 2.20 & Low \\
\hline 20 & $\begin{array}{l}\text { Voice re-enforcement system } \\
\text { for the lecture halls. }\end{array}$ & 750 & 2025 & 2.70 & High \\
\hline 21 & $\begin{array}{l}\text { Office equipment for proper } \\
\text { storages and documentations. }\end{array}$ & 750 & 1200 & 1.60 & Low \\
\hline 22 & $\begin{array}{l}\text { Air conditioners for staff } \\
\text { offices. }\end{array}$ & 750 & 1200 & 1.60 & Low \\
\hline 23 & $\begin{array}{l}\text { Office cabinets for staff } \\
\text { offices. }\end{array}$ & 750 & 1200 & 1.60 & Low \\
\hline 24 & $\begin{array}{l}\text { Audio-visual aids for } \\
\text { teaching and learning. }\end{array}$ & 750 & 1800 & 2.40 & Low \\
\hline 25 & $\begin{array}{l}\text { Charts for teaching and } \\
\text { learning. }\end{array}$ & 750 & 1875 & 2.50 & High \\
\hline 26 & $\begin{array}{l}\text { Electronic text books for } \\
\text { research. }\end{array}$ & 750 & 900 & 1.20 & Low \\
\hline & Grand mean & 31.40 & & \\
\hline
\end{tabular}

Findings made from the analysis of data presented on table two shows that the TET Fund's policy on the provision of some essential instructional materials and equipments like library books, electronic media, data projectors, magnetic boards and voice re-enforcement system were rated high. On the other hand, other instructional materials and equipments like laboratory apparatuses, personal computers, necessary engineering machines, document cameras, office equipments, air conditioners, office cabinets, Audio-Visual aids and electronic text books were all rated vary low. On the whole they obtained grand mean of 31.40 is lower than the expected grand mean of 37.50 which is an indication that the overall extent to which Tertiary Education Trust Fund's policy on the provision of instructional material and equipment for teaching and learning has been implemented for universities improvement in the South-East, Nigeria is low.

Table 3: Summary of ANOVA test for significant difference between the mean rating of the HODs, Deans of faculties, and TET Fund committee members on the extent of implementation of TET Fund policy on provisions of essential physical infrastructure for teaching and learning has been implemented for universities improvement.

SUMMARY OF F- RATIO TABLE

\begin{tabular}{|l|l|l|l|l|l|l|}
\hline $\begin{array}{l}\text { Source of } \\
\text { Variance }\end{array}$ & $\begin{array}{l}\text { Sum } \\
\text { of SQ }\end{array}$ & $\mathrm{d} \mathrm{f}$ & $\begin{array}{l}\text { Alpha } \\
\alpha\end{array}$ & $\begin{array}{l}\text { Mean } \\
\text { SQ }\end{array}$ & $\begin{array}{l}\text { F. Ratio } \\
\text { Cal }\end{array}$ & $\begin{array}{l}\text { F, Ratio } \\
\text { Table }\end{array}$ \\
\hline Btw groups & 2.73 & 2 & 0.05 & 1.36 & & \\
\cline { 1 - 5 } $\begin{array}{l}\text { Within } \\
\text { groups }\end{array}$ & 5.30 & 7.5 & & 0.18 & \multirow{2}{*}{7.5} & 5.85 \\
\cline { 1 - 4 } Total & 8.03 & & & & & \\
\hline
\end{tabular}

The results of the f-test show that the calculated F-value is 7.5 whereas the $\mathrm{F}$ table value at 0.05 level of significance is 5.85 . Since the calculated value is greater than the table value therefore the null hypothesis which stated that there is no significant difference between the mean ratings of the respondents on the extent to which The Tertiary Education Trust fund policy on provisions of essential physical infrastructure for teaching and learning has been implemented for universities improvement in South-East, Nigeria is rejected.

Table 4: Summary of f-test for significant difference between the mean ratings of the HODs, Deans of faculties and TET Fund committee members on the extent to which Tertiary Education Trust fund policy on the provisions of instructional materials and equipments for teaching and learning has been implemented for universities improvement in South- East, Nigeria

SUMMARY OF F - RATIO TABLE

\begin{tabular}{|c|c|c|c|c|c|}
\hline $\begin{array}{c}\text { Source } \\
\text { of } \\
\text { variation }\end{array}$ & $\begin{array}{c}\text { Sum of } \\
\text { sq }\end{array}$ & Df & $\begin{array}{c}\text { Alpha } \\
\alpha\end{array}$ & Mean sq & F-ratio \\
\hline $\begin{array}{c}\text { Btw } \\
\text { group }\end{array}$ & 0.37 & 2 & 0.05 & 0.19 & \\
\hline $\begin{array}{c}\text { Within } \\
\text { group }\end{array}$ & 15.5 & 42 & & 0.37 & 0.51 \\
\hline TATOL & 15.5 & 44 & & & \\
\hline
\end{tabular}

The result of the f-test shows that the calculated f-value is 0.51 , whereas for one tailed test, the table $\mathrm{f}$-value at 0.05 level of significance is 5.85. This shows that the computed mean rating of the respondents is significantly lower than the critical table value. For this reason, the null hypotheses are rejected.

\section{DISCUSSION OF RESULT}

\section{Essential Physical Infrastructure}

The findings of the study reveals that the overall extent to which TET Fund policy on provision of Essential Physical Infrastructure for teaching and learning has been implemented for universities improvement in the South-East, Nigeria is low. However, there is a significant difference in the mean ratings of the opinion of the respondents on the result. This means that the null hypothesis is rejected. The result shows that some essential physical infrastructure like laboratory building, lecture halls, power, ICT blocks were rated high while others like Administrative blocks, staff offices, water resource, library buildings, auditoria, staff quarters were all rated low. On the whole therefore, the obtained grand mean of 22.9 is lower than the expected grand mean of 27.5 which shows that the extent to which TET Fund has implemented this particular policy objective in the South East is low. This finding agrees with Ekankumo and Kenebaradikumo (2014) who observed that funds from TET Fund is far minimal to go round all tertiary institutions in Nigeria. The findings also agrees with Saint in Okojie (2007) who asserts that university system has not had the financial resource necessary to maintain quality education in the midst of significant enrolment explosion, the view which also agreed with Ubogu (2011) who maintained that in the past three decades higher education in Nigeria has witnessed a significant growth in terms of expansion of access through increase in enrolment and establishment of additional institutions, however, Ubogu asserted that it is saddening to note that many of the indices 
that can guarantee qualitative education are not taken into consideration in the country's quest to meet qualitative targets. However, the finding also indicated a significant difference in the mean ratings of the opinion of the HODs, Deans of faculties and TET Fund committee members. This may be why the findings of Udu and Nkwede (2014) towed a different line who asserts that TET Fund interventions in Nigerian universities especially Ebonyi state university (EBSU) has impacted positively on the infrastructural development of the institution.

The reason for this discrepancy may be due to some institutions inability to access the available TET Fund meant for them for reasons best known to them. It should also be pointed out that these institutions are not of the same age. Some of the older ones might have already developed infrastructurally and might have been receiving TET Fund interventions before the newer ones.

\section{Instructional Materials and equipment}

The findings also shows that the TET Fund policy on the provision of instructional materials and equipments for teaching and learning has been implemented for the universities improvement in the South-East, Nigeria to a low extent, and there is no significant difference in the mean ratings of the HODs, Deans of faculties and TET Fund committee members of the universities under study on this result. This shows that the null hypothesis is accepted.

The result actually indicates that instructional materials like library books, electronic media, data projectors, magnetic boards, voice re-enforcement system and charts are rated high by the respondents, while materials like laboratory apparatus, personal computers, necessary engineering machines, documents, Air conditioners, office cabinets, Audio-visual aids and electronic text books are rated low. On the whole therefore the obtained ground mean of 31.415 is lower than the expected grand man of 37.5 which is an indication that the overall extent to which TET Fund has implemented its policy on these for universities improvement in the South East is low. The finding also indicated that there is no significant difference in the opinion of the respondents on this result. This means that in respect to TET Fund implementations of policy on the provision of Instructional materials/equipment in the South-East universities, the general opinion of the HODs, Deans of faculties, and TET Fund committee members of the universities in the South-East is that it is low. This finding agrees with Akintoye in Ubogu 2011) assertions that the byeffects of dwelling finances in higher institutions (Nigerian universities) is explicated in many mechanisms such as curtailment in the purchase of library books, chemicals, and basic laboratory equipments, among others. The reason for this may be due to inability of these universities in the South East accessing the funds for these instructional materials and equipment as provided by TET Fund either due to their inability to retire previously accessed fund. This may also be blamed on the universities leadership. It is of note that some leaders are out- reaching and out- going whereas some are docile and unconcern.

\section{Educational Implications of the Findings}

1. The extent to which Education Trust Fund policy on provisions of essential physical infrastructure for teaching and learning has been implemented for the universities improvement in the South-East, Nigeria is low. This could imply that the universities in the South - east, Nigeria lack adequate and essential physical infrastructure for teaching and learning.

2. The Tertiary Education Trust Fund's policy on provisions of essential instructional materials and equipments for teaching and learning has been implemented for the universities improvement in the South-East, Nigeria to a low extent. This could imply that teaching and learning in these institutions may be ineffective.

\section{RECOMMENDATIONS}

In the light of the findings of this study, the researcher therefore recommends as follows:-

1. That the Board of Trustees (BoT) of TET Fund should diversify provisions of essential physical infrastructure to cover other areas like provision of administrative buildings for effective management of teaching and learning, provision of water resource, hostel accommodation for students, auditoria ,staff quarters and staff offices.

2. That the Board of Trustees (BoT) of TET Fund should improve to a large extent its policy on the provisions of instructional materials and equipment as these are the live wires of teaching and learning especially in the areas of laboratory apparatuses, personal computers, necessary engineering machines, document cameras, air conditioners, office cabinets, and audio-visual aids in the universities in the South-East, Nigeria.

\section{CONCLUSION}

TET Fund as an intervention agency for rehabilitation, reconstruction and restoration of tertiary institutions in the country is doing its best to implement policies on provision of funds for universities improvement especially, but much work still need to be done. The board of trustees needs to step up more to properly supervise the utilization of these fund for better result. In infrastructural development, staff quarters and well equipped offices are very essential live wires of teaching and learning in any educational institution. TET Fund in the country has been doing its best through the board of trustees, but they should consider some minute but salient areas the lecturers are in dare need of for proper teaching and better learning which brings about the desired improvement. 


\section{Limitations of the Study}

The study made use of questionnaire for data collection. Though, the researcher had wanted to use inspection and observation for data collection. The use of questionnaire may lead to inadequate responses. However, the respondents were well guided and directed. The checklist that was used with questionnaire helped to confirm that the questionnaire responses were real.

The institutions that were investigated were not all at the same level of development and need. Some have existed for decades while some are new. As a result the intervention of TET Fund in the institutions may not be equal. The above stated challenges notwithstanding, the findings are very valid and reliable.

\section{Suggestions for Further Researches}

1. It is suggested that this work be repeated in other geo political zones in Nigeria

2. It is also suggested that a study be conducted on monitoring of TET Fund projects in Nigeria.

3. The researcher still suggests that this study may be repeated using inspection and observation methods.

\section{REFERENCES}

[1] Assman, J. (2002). The mind of Egypt: History and meaning in the time of the pharohs. P. 127. Enlyclopaedia Britannica.
[2] ASCC (2014). Tools and Materials for quality teaching and learning, Retrieved from

http://www.facebook.com/unite4education.

[3] Australian National University (2014). Teaching room support and equipment. Retrieved from http://itservices. Anu.Edu.au/teachingand-learningsupport/teaching.

[4] Ekankumo, B. and Kemebaradikuno, N. (2014). Quality financing of higher education in Nigeria: A nostrum for the provision of quality education. Journal of Education and Practice, 5 (19) 62-63.

[5] Federal Republic of Nigeria (FRN) (2013). National Policy on education NERDC: Abuja

[6] Fulmer, J. (2009). "what in the world is infrastructure? "PEI Infrastructure Investor (July/August): 30-32.

[7] Hornby, A.S (2000) Oxford Advanced Learners Dictionary of current English ( $6^{\text {th }}$ ed). London: Oxford Press.

[8] Idogho, P.O (2011). Higher education in Nigeria and the Challenges ahead. Nigeria-European Journal of Education Studies $3(2), 44-41$.

[9] Auchi: Ozean publications.

[10] Ike, G.A; Chemezie, O.S and Iwu, A.O. (2002). New educational technology. Owerri: Onii Publishing House.

[11] Nwakaudu, S. (2013). TET Fund and Infrastructural development in Nigeria Federal Universities. Retrieved from www.Thisdaylive.com /article/infrastructural development in Nigeria Universities.

[12] TET Fund (2014). Tertiary Education trust fund Interactive workshop on TET Fund: Guildlines for accessing Intervention funds.

[13] UDU, L.E. \& Nkwede, J.O (2014). Tertiary Education Trust Fund Interventions and sustianble Development in Nigerian universities: Evidence from Ebonyi State University, Abakiliki 7(4), Canada: Canada center of Science and Education. 